\title{
AN EMPIRICAL STUDY ON IMPACT OF SUSTAINABILITY-ORIENTED TOTAL QUALITY MANAGEMENT PRACTICES ON ORGANIZATIONAL PERFORMANCE IN UAE BASED ORGANIZATION
}

\author{
DR. JACOB CHERIAN \& DR. GAIKAR VILAS B \\ ${ }^{1}$ Associate Professor of Management, Abu Dhabi University, United Arab Emirate (UAE) \\ ${ }^{2}$ Associate Professor, Department of Economics, Smt. CHM. College, University of Mumbai, India
}

\begin{abstract}
The globalization capability, the vivid competition, the continual technological evolution imposes organizations to provide quality services and products in highly competitive prices preferably in economic decline environment. Survival and evolution of the organizations is based on tool called quality. To achieve quality, a well-known and effective system used in organizations is Total Quality Management (TQM). In order to survive in the modern economy, performance level of each and every organization is highly significant, which can be implemented through TQM. Recent studies on TQM has declared that it is capable of fostering improvement in service or product, in financial performance, and in reducing costs, whilst providing high satisfaction to customer and employees.

In spite of the fact that favorable advantages of TQM are huge, its execution is supported only when it has an important and significant effect on financial performance of organization. The major motive of this research is to establish TQM practices employed by Royal Jet, UAE and examine their own financial performance by adapting TQM. The ultimate objective of this research is to find out the impact of TQM on financial performance of Royal Jet. Financial performance of Royal Jet is considered as dependent variable. The top management involvement, employee performance and customer satisfaction are considered as independent variables. The relationship between the dependent and independent variables is analyzed through case study to find the impact of total quality management on financial performance.
\end{abstract}

KEYWORDS: Quality, Financial Performance, Total Quality Management \& Royal Jet

Received: Jun 08, 2020; Accepted: Jun 28, 2020; Published: Sep 17, 2020; Paper Id.: IJMPERDJUN20201302

\section{INTRODUCTION}

Total Quality Management (TQM) is termed as guiding principles and also as a philosophy. The principles of TQM represent base of extraordinary organization (Rigby, D., \& Bilodeau, B, 2015). TQM can serve as a universal method to enhance the surveillance of modern economies. A major aspect of ensuring that TQM is successful in its application is dependent on the effective incorporation of the diverse subsystems of management. Basic resources and fundamental techniques can be implemented using TQM. Implementation of TQM remains as challenge and also support to the management (Al-Ettayyem, R., \&Zu'bi, M. F., 2015). Improved services and products can be generated by successful implementing TQM. In turn TQM produces reduction in cost, highly satisfied employees and customers, and improvement in financial performance (Rigby, D., \& Bilodeau, B., 2015 \& Kurt, A., \&Zehir, C., 2016).

The perpetually enhancing worldwide rivalry and expanding demands for highly qualified products by the clients have made organizations comprehend that the main method for survival in the business sector is to produce 
and deliver good quality products to address clients' necessities. Numerous organizations, in this manner, spend extensive amount of investments in exercises concerning with enhancing products and services. The endless applicability of TQM has made it to procure acknowledgment as a standout amongst the continuous quality system frameworks. TQM expands the reliability and satisfaction of consumer through the cooperation of all work forces (Demirbag et al, 2006). The primary motive of TQM is to execute a management system and hierarchical society that guarantees the consumer reliability since clients who are more delicate to quality benchmarks enhance their desires continuously (Eriksson, H. and Hansson, J., 2002).

\subsection{Philosophy of TQM}

- TQM is known by a few different names, but the goal of TQM is common.

- Customer satisfaction

- Continual improvement in productivity and quality (Lau, et al, 2016)

The premise of TQM philosophy and its process can be expressed essentially: to plan and deal with a procedure that fulfills the client in an inexorably viable way. In a few organizations along these lines of life is called "Total Quality Control".

TQM depends on various thoughts. It implies contemplating quality regarding all elements of the endeavor, and it is a start-finish procedure that coordinates interrelated functions in all levels. It is a system approach which determines communication between components of the organization. In this way, in approach of TQM, the general viability of the system is higher than the sum total of the individual adequacy of the subsystems. The subsystems incorporate the majority of the authoritative capacities in the lifecycle of a product, e.g. production, design, field service, planning and distribution, etc. Management is represented as sub-system in TQM methodology. Subsequently, the management system additionally requires coordination with the others, through a procedure that spotlights on fulfillment, the devices of value, and worker change. The expression "TQM" incorporates the expression "quality" and "management." In TQM rationality, management is seen as giving the driving force to make quality as guiding procedure of organization(Hohan, A. I. et al, 2015).

\subsection{Importance of Financial Performance Measures}

Concentrating on whether quality activities are practical requires assessments of results, in particular execution measures. It is vital to gauge the achievement of new activities like TQM with measures of monetary execution for the following two reasons.

- the most advancements and ventures are supported on the premise of their effect on money related and bookkeeping measures, not operational measures.

- The financial execution measures are the main inside created measures that straightforwardly reflect whether the organization's procedure, usage, also, execution are producing riches by adding to firm esteem.

Therefore, despite the fact that effects of activities are not effortlessly evaluated, financial execution measures are the most essential measures of the adequacy of these activities. Financial execution measures demonstrate whether the organization's technique, usage, and execution are adding to main concern to change. Regular financial objectives need to do with productivity and profitability (O’Neill, P., et al, 2016 \&Valmohammadi, C., \&Roshanzamir, S., 2015). 


\section{LITERATURE REVIEW}

In the era of globalization, quality is the essential component of success. For the competence of good market position, every organization has to implement an effective management strategy e.g. Total quality management, for better performance. TQM is defined as an universal approach and philosophy of management which pursues the continuous improvement in operations and functions of an organization to produce product and to deliver service that satisfies the consumer necessities (Demirbag et al, 2006). TQM is a strategy to improve the quality and performance of organization's output to meet the demands of consumers (Kaur, Singh, \& Ahuja 2012), and to achieve success for long term (Sharma \&Kodali, 2008).During the initial stages TQM strategy was mainly employed in manufacturing sector. Since TQM has attained highest reputation as one of the main element of competitive advantage in service sector as well (Bhat and Rajashekhar, 2009; Faisal, Rahman, \& Qureshi, 2011).

Total Quality grasps not just quality of particular service or product, but complete procedure what an organization does, to determine the opinion not only of its prompt clients or end-clients, yet its notoriety in the community everywhere (Shahin and Dabestani, 2011).

Islam and Haque (2012)stated that TQM depends on the following 8 elements such as quality management generation, enhancement of team work, quality control practice techniques and tools, customer focus, supplier relationship focus, benchmarking, continual improvement in processes and employee performance.

Sufficient time has to be given by the organization for obtaining department to distinguish low cost, excellent suppliers and to break down the data they submit. An unlikely due date, for case, can prompt poor choice of suppliers taking into account inadequate data about supplier capabilities. (Islam. A. \& Haque, A. F. M.2012)

In TQM, a focal center value is that all products and procedures ought to dependably have a client focus. Quality ought to be esteemed by the clients and ought to dependably be placed in connection to their requirements and desires. To concentrate on the client implies, in this manner, that one tries to discover the clients' needs and values by leading business sector examinations and after that attempting to satisfy the business sector desires while methodically creating and fabricating the item. Each worker has clients inside the organization, inner clients, and keeping in mind the end goal to benefit an occupation their necessities additionally must be satisfied. (Nagaprasad,H. what's more, Yogesha, B 2009).

A significant part of the work inside an organization can be looked upon as a procedure, which implies a redundant arrangement of exercises. The objective of the procedure is to create products or managements, which ought to fulfill the client. The end product of concentrating on procedures is that the emphasis is not on results. Rather the outcome is the dependent variable. The outcome originates from whatever procedure is taken after; procedure drives result. The procedure creates information that shows how well the procedure is fulfilling its clients. (Bergman and Klefsjö, 2003).

For TQM execution to be effective, top management ought to be a champion in its usage by giving leadership and connect with all representatives in the work of fulfilling the client with a persistently enhanced quality. This implies persistent change ought to be rehearsed all over the place in the procedures and that the inclusion of all workers at each level ought to be encouraged. This core esteem likewise incorporates suppliers, who after some time will get to be accomplices by working with engaged representatives to the event of the organization (Islam. A. also, Haque, A. F. M.2012). 
The work based on the skillset and cooperation of each worker and his or her comprehension of what are required. Top management ought to be champion in preparing all representatives to give the learning required on the mission, vision, direction, and methodology of the organization and the skillset they have to actualize TQM and purpose issues. Commitment keywords are data, delegation as well as training (Witjaksono, A. D., 2012).

The impact of executing Total Quality Management (TQM) on financial execution was examined in Boutan Industrial Corporation (BIC). The study was reasoned that execution of TQM in BIC has critical and positive impact on quick ratio, return on assets, current ratio, return on equity ratio, all out resources turnover proportion and financial execution, and has negative impact on obligation to aggregate resources proportion. Notwithstanding this outcome, the distinction amongst BIC and their comparison in organizations demonstrates that the normal monetary execution of BIC contrasted with standard organizations in the period after usage is higher than its normal in the period before usage, i.e. financial execution of this company contrasted with the period before usage is enhanced (Arash Shahin 2011).

The success factor implementation of TQM in airline industry was analyzed to enhance the performance and to find out the implementation impediments in TQM (Charu Gupta, Dr. R. M. Belokar 2012).

\section{METHODOLOGY}

Role of total quality management in the improvement of financial performance of Royal Jet is done by qualitative method. The study sample for this specific investigation is top management, and middle level and junior level employees from Royal Jet in Abu Dhabi, UAE. The total sample size is 300 . When coming to the data for analysis, primary data is taken for the analysis of financial performance. In order to identify the role of total quality management in improving the financial performance of Royal Jet is measured using "LIKERT" scale. The outcome of the survey will be utilized for the legitimacy of present system. There framework for the study is explained as follows.

\subsection{Framework for the Study}

In common, there are number of variables which can provide impact on financial performance of an organization due to total quality management. The variables are top management commitment, communication, customer satisfaction, benchmarking, supplier relationship, employee commitment, involved process, increased load factor, top management commitment, employee commitment, training and education, empowerment of employees, coordination and teamwork, improved service quality, continuous improvement culture, process improvement, on time performance, etc. From the above I have chosen essential 3 independent variables such as top management involvement, employee commitment, and customer satisfaction with respect to the dependent variable such as financial performance. The conceptual framework for this research is represented in the following figure 1. 


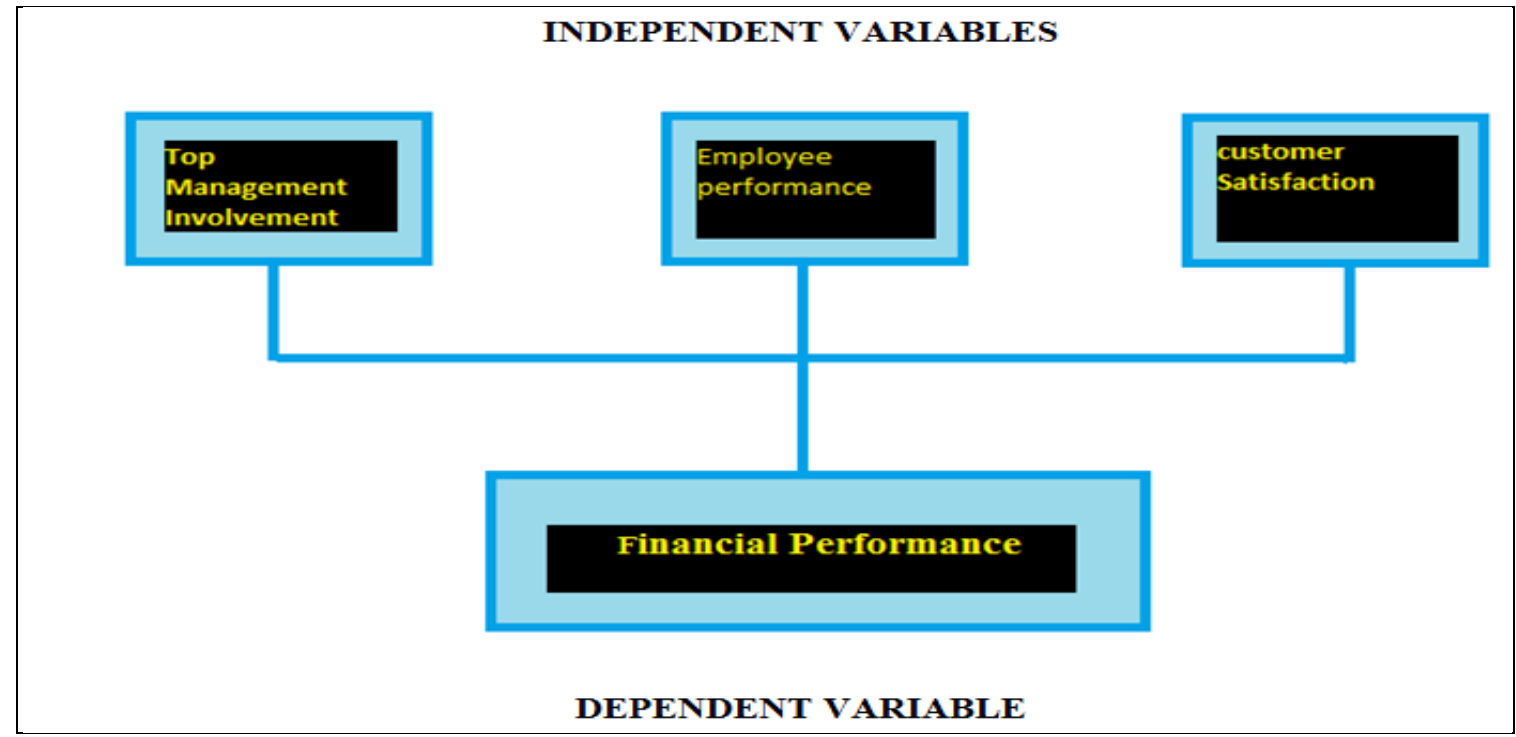

Figure 1: Framework.

\subsection{Hypotheses for the Study}

- H0: Customer satisfaction does not play a major in improvement of financial performance of Royal Jet.

- H1: Customer satisfaction plays a major in improvement of financial performance of Royal Jet.

- H0: There is no impact on training provided to employees by top management.

- $\quad \mathrm{H} 2$ : There is significant impact on training provided to employees by the top management.

- H0: TQM as a best strategy does not influence financial performance of Royal Jet through employee performance and customer satisfaction.

- H3: TQM as a best strategy highly influences financial performance of Royal Jet through employee performance and customer satisfaction.

\section{ANALYSIS AND FINDINGS}

Primary data is collected for analyzing impact of TQM on financial performance. Analysis of primary is carried out in the following method.

\subsection{Hypotheses $\mathrm{H}_{1}$ - Analysis}

- $\quad H_{0}$ : Customer satisfaction does not play a major in improvement of financial performance of Royal Jet.

- H1: Customer satisfaction plays a major in improvement of financial performance of Royal Jet.

The collected data for analyzing the role of customer satisfaction for the improvement of financial performance of Royal Jet is shown in the figure 1. Opinion of participants on customer satisfaction in Royal Jet is explained in the figure 1. The table 1 conveys the opinion of participants about satisfaction of customer doe to the involvement of employees in delivering high quality service. 
Table 1: Data Collected based on the Satisfaction Level of Royal Jet Customers Due to the Dedication and WorkCommitment of Royal jet Employees Towards Provision of Services.

\begin{tabular}{|l|c|c|}
\hline Parameters & $\begin{array}{c}\text { Effective Service Operation Delivered by } \\
\text { Employees in Order to meet Customers' } \\
\text { Requirements to Satisfy them }\end{array}$ & $\begin{array}{c}\text { Improvement in Financial Performance of } \\
\text { Royal Jet through Effective Delivery of high } \\
\text { Quality Service }\end{array}$ \\
\hline $\begin{array}{l}\text { Strongly } \\
\text { Agree }\end{array}$ & 82 & 79 \\
\hline Agree & 69 & 67 \\
\hline Neutral & 51 & 55 \\
\hline Disagree & 54 & 51 \\
\hline $\begin{array}{l}\text { Strongly } \\
\text { Disagree }\end{array}$ & 44 & 47 \\
\hline \multicolumn{1}{|c|}{ Total } & $\mathbf{3 0 0}$ & $\mathbf{3 0 0}$ \\
\hline
\end{tabular}

The table 1 evidently explains that high number of participants agrees that financial performance of Royal Jet is improved due to the effective service operation delivered by employees in order to meet customers' requirements having significant impact on financial performance. It is highly accepted factor that financial performance of organization is highly relies on the satisfaction of customer in a higher level. Due to the nature of service they provide, it is necessary that every service industry has to rely on long-term relationship with customers. Satisfaction of customers will be developed over time. The above results show that there is continuous involvement of Royal Jet in developing satisfaction of customer.



Figure 1: Data Collected based on Customer Satisfaction.

4.1.1 Chi-Square Test for Hypotheses $\mathrm{H}_{1}$ :

Table 2: Chi-Square Test Values for Hypotheses H1

\begin{tabular}{|c|c|c|c|c|}
\hline & Df & Asymp. Sig. (2-sided) & Exact Sig. (2-sided) & Exact Sig. (1-sided) \\
\hline Pearson Chi-Square & 4 & 0.214 & & \\
\hline Continuity Correction $^{\mathrm{b}}$ & 4 & 1.000 & & \\
\hline Likelihood Ratio & 4 & .081 & & \\
\hline Fisher's Exact Test & & & 1.000 & .500 \\
\hline Linear-by-Linear Association & 4 & 49.1 & & \\
\hline $\mathrm{N}$ of Valid Cases ${ }^{\mathrm{b}}$ & 4 & 0.214 & & \\
\hline
\end{tabular}


The Chi-square value for the improvement of financial performance of Royal Jet due to attained customer satisfaction is 15.000 with df value of 4 .

\subsection{Hypotheses $\mathrm{H}_{2}$ - Analysis}

- $\mathrm{H}_{0}$ : There is no impact on training provided to employees by top management.

- $\quad \mathrm{H}_{2}$ : There is significant impact on training provided to employees by the top management.

The collected data for analyzing the role of top management in providing training to the employees of Royal Jet, as shown in figure 2. The views and opinions of participants on training provided by the top management in order to deliver high-quality service are explained in figure 2 . The table 2 portrays the views of employees as well as top management of Royal Jet.

Table 3: Data Collected based on Training Provided by Top Management to Employees

\begin{tabular}{|l|c|c|}
\hline Parameters & $\begin{array}{c}\text { Training Provided By Top Management } \\
\text { of Royal Jet }\end{array}$ & $\begin{array}{c}\text { Significant Improvement in } \\
\text { Employee Performance }\end{array}$ \\
\hline Declining & 38 & 37 \\
\hline High & 85 & 84 \\
\hline Moderate & 72 & 72 \\
\hline Very High & 105 & 107 \\
\hline \multicolumn{1}{|c|}{ Total } & $\mathbf{3 0 0}$ & $\mathbf{3 0 0}$ \\
\hline
\end{tabular}

The impact of training provided by the top management to employees having high significance on the performance of employees is clearly shown in the table 3. Around $62 \%$ participants state that there is high impact on performance of employees, which assists top management to analyze their managerial level to take further step. Performance of employees will be continuously increasing by continuous monitoring and analysis process.

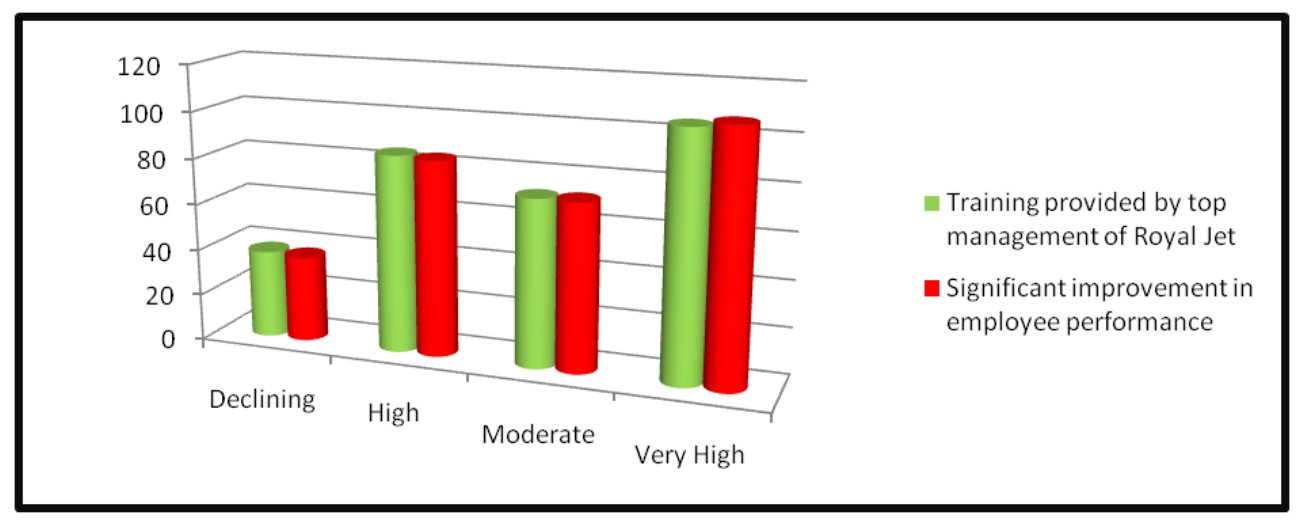

Figure 2: Data Collected based on Training Provided by Top Management.

\subsubsection{ANOVA Test for Hypotheses $\mathrm{H}_{2}$ :}

ANOVO test is carried out for analyzing training provided by top management for development of employee performance.

Table 4: ANOVA Test for Analyzing Training Provided by Top Management

\begin{tabular}{|l|c|cc|c|}
\hline \multicolumn{1}{|c|}{ Variables } & \multicolumn{1}{c|}{ N } & \multicolumn{1}{c|}{ Mean } & \multicolumn{1}{c|}{ Std. Deviation } \\
\hline Declining & 75 & 2.14 & & 2.992 \\
\hline High & 75 & 3.21 & 0.21 \\
\hline Moderate & 75 & 6.75 & & 9.214 \\
\hline Very High & 75 & 12.4 & 6.247 \\
\hline \multicolumn{1}{|c|}{ Total } & $\mathbf{3 0 0}$ & \multicolumn{2}{c|}{$\mathbf{2 4 . 5}$} & $\mathbf{1 8 . 6 6 3}$ \\
\hline
\end{tabular}


Table 5: Significance Test for Analyzing the Training Provided by

Top Management for Improving Employee Performance

\begin{tabular}{|l|l|l|c|c|}
\hline & \multicolumn{1}{|c|}{ df } & \multicolumn{1}{|c|}{ Mean Square } & \multicolumn{1}{c|}{ F } & Sig. \\
\hline Between Groups & 5 & 192.142 & 21.246 & .009 \\
\hline Within Groups & 9 & 9.300 & & \\
\hline Total & 14 & & & \\
\hline
\end{tabular}

The ANOVA analysis of the collected data as shown in tables 4 and 5 has the significance of the 0.009 which means that there is development in performance of employee through training provided by top management. The primary data analysis demonstrates that training provided by top management is major reason for performance improvement of employees, which will lead to higher customer satisfaction.

\subsection{Hypotheses $\mathrm{H}_{3}$ - Analysis}

- $\mathrm{H}_{0}$ : TQM as a best strategy does not influence financial performance of Royal Jet through employee performance and customer satisfaction.

- $\mathrm{H}_{3}$ : TQM as a best strategy highly influences financial performance of Royal Jet through employee performance and customer satisfaction.

The analysis of primary data clearly indicates that TQM is best strategy to improve the financial performance of Royal Jet.

The figure 3 explains the success factor for the improvement of financial performance of Royal Jet. The data collected reveals that TQM is best strategy for the development of financial performance through employee performance and customer satisfaction. From table 6, it is clear that improvement of financial performance through the implementation of TQM.

Table 6: Data Collected based on TQM as Best Strategy for the Improvement of Financial Performance of Royal Jet

\begin{tabular}{|l|c|c|}
\hline Parameters & $\begin{array}{c}\text { TQM as a Best Strategy for Improving } \\
\text { Employee Performance and Customer } \\
\text { Satisfaction }\end{array}$ & $\begin{array}{c}\text { Significant Improvement in Financial } \\
\text { Performance of Royal Jet through the } \\
\text { Implementation of TQM }\end{array}$ \\
\hline Agree & 70 & 73 \\
\hline Disagree & 65 & 66 \\
\hline Neutral & 62 & 54 \\
\hline $\begin{array}{l}\text { Strongly } \\
\text { Agree }\end{array}$ & 77 & 79 \\
\hline $\begin{array}{l}\text { Strongly } \\
\text { Disagree }\end{array}$ & 26 & 28 \\
\hline \multicolumn{1}{|c|}{ Total } & $\mathbf{3 0 0}$ & $\mathbf{3 0 0}$ \\
\hline
\end{tabular}

TQM is proven to be an excellent strategy for the development of financial performance, which is clearly shown in the above table. The most participants agree that TQM enables improvement in employee performance and customer satisfaction; in turn TQM is a best strategy with its complete opportunities to increase the financial performance of Royal Jet, when compared to other strategies. This gives motivation to every organization irrespective of the size to get involved in implementation of TQM. 


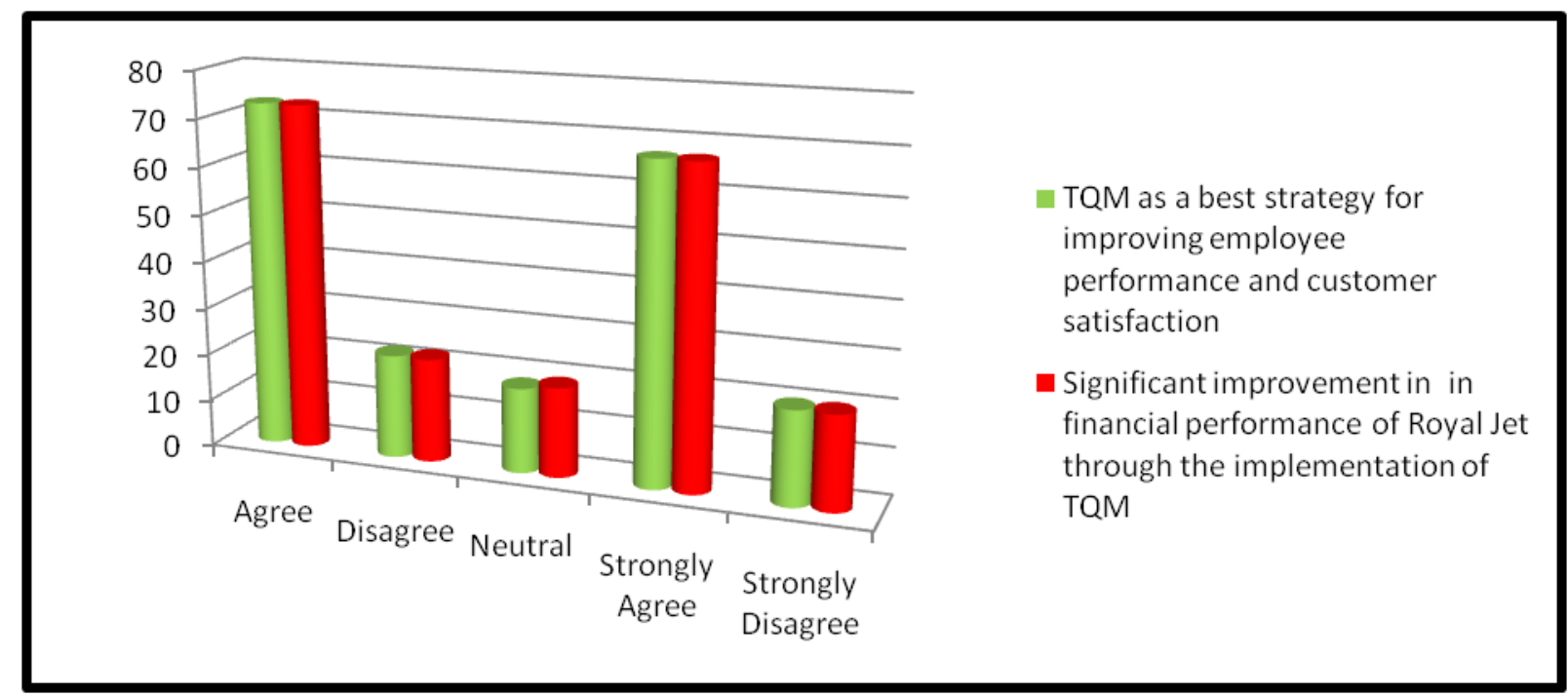

Figure 3: Data Collected based on TQM as Best Strategy for the Improvement of Financial Performance of Royal Jet.

\subsubsection{Correlation Analysis - Hypotheses H3:}

Table 7: Correlation Analysis for Hypotheses $\mathbf{H 3}$

\begin{tabular}{|c|c|c|c|}
\hline \multicolumn{2}{|l|}{ Particulars } & $\begin{array}{c}\text { Variable } \\
\text { X }\end{array}$ & $\begin{array}{c}\text { Variable } \\
\text { Y }\end{array}$ \\
\hline \multirow{3}{*}{$\begin{array}{l}\text { TQM as a best strategy for improving employee performance and } \\
\text { customer satisfaction }\end{array}$} & $\begin{array}{l}\text { Pearson } \\
\text { Correlation }\end{array}$ & 1 & 0.02 \\
\hline & Sig. (2-tailed) & & .9910 \\
\hline & $\mathrm{N}$ & 300 & 300 \\
\hline \multirow{3}{*}{$\begin{array}{l}\text { Significant improvement in in financial performance of Royal Jet through } \\
\text { the implementation of TQM }\end{array}$} & $\begin{array}{l}\text { Pearson } \\
\text { Correlation }\end{array}$ & $0.025^{* *}$ & 1 \\
\hline & Sig. (2-tailed) & .8470 & \\
\hline & $\mathrm{N}$ & 300 & 300 \\
\hline
\end{tabular}

Correlation Analysis is a tool to identify the relation between two factors, if the correlation analysis for the variables is significant than the hypotheses has been satisfied. The table 7 explains that correlation analysis for role of TQM in improving financial performance of TQM through the 100\% employee performance and higher level customer satisfaction is 0.01 . The analysis result revealing that significance value is around 0.99, which means TQM is the best strategy for the development of financial performance through its implementation.

\section{CONCLUSIONS}

The necessity to identify the relationship between customer satisfaction and profitability has never been critical. It is often believed that financial performance of service industry relies highly on the generation of highly satisfied customers. Irrespective of the change in economy, higher level satisfaction of customers will lead every organization to get rigid correction with financial performance in terms of customer retention and new business generation. Customer satisfaction is highly sensitive to changes in present scenario. Customer satisfaction clearly explains the levels of relative revenue growth and profitability. One thing is highly evident from our research that there is a direct link between employee performance and customer satisfaction, and between financial performance and customer satisfaction. Since TQM is management pattern according to the principles of employee performance, customer satisfaction and continuous improvement. Employee 
performance is based on the factor that the top level management provides training due to which the employees will put their fullest effort to satisfy the needs of the customers. The role of top management was planned, structured and excited by the usage of best strategy, TQM. Through the assistance of TQM, Royal Jet has identified the optimal ways to satisfy the customer needs in order to attain profitability. From the research, it is evident that TQM is best strategy for the improvement of financial performance of Royal Jet. Royal Jet has generated superior profitability which was obtained through the higher quality of service provided by the employees to the customers. Royal Jet, as organization with high quality foundation has proven to achieve improved financial performance, through the implementation of TQM.

\section{REFERNCES}

1. Al-Ettayyem, R., \&Zu'bi, M. F. (2015). Investigating the Effect of Total Quality Management Practices on Organizational Performance in the Jordanian Banking Sector. International Business Research, 8(3), 79.

2. Attafar, A., Shahin, A., \&Kheradmandnia, M. (2016). The impact of TQM practices on organizational learning case study. International Journal of Quality \& Reliability Management, 33(5), 574-596.

3. Attafar, A., Shahin, A., \&Kheradmandnia, M. (2016). The impact of TQM practices on organizational learning case study. International Journal of Quality \& Reliability Management, 33(5), 574-596.

4. Bergman, B. and Klefsjo; B. (2003), Quality from Customer Needs to Customer Satisfaction, 2nd ed., Studentlitteratur, Lund.

5. Demirbag, M., Tatoglu, E., Tekinkus, M. and Zaim, S. (2006). An analysis of the relationship between TQM implementation and organizational performance evidence from Turkish SMEs. Journal of Manufacturing Technology Management, 17(6), 829-847.

6. Eriksson, H. and Hansson, J. (2002). The impact of TQM on financial performance. Measuring Business Excellence, 6(4), 4454.

7. Gupta, C., \&Belokar, R. M. Applications of Total Quality Management in Indian Airline Industry.

8. Hohan, A. I., Olaru, M., \& Keppler, T. (2015). Integration of risk management practices in the framework of an integrated management system environment-health and safety-information security. Calitatea, 16(S1), 289.

9. Islam, M. R., Haque, M. E., Giasuddin, M., Chowdhury, E. H., Samad, M. A., Parvin, R\&Monoura, P. (2012). New introduction of clade 2.3. 2.1 avian influenza virus (H5N1) into Bangladesh. Transboundary and emerging diseases, 59(5), 460-463.

10. Islam. A. and Haque, A. F. M. (2012). Pillars of TQM implementation in manufacturing organization- an empirical study, Journal of Research in International Business and Management, Vol. 2(5) pp. 128-141.

11. Kaur, M., Singh, K., \& Singh Ahuja, I. (2012). An evaluation of the synergic implementation of TQM and TPM paradigms on business performance.International Journal of Productivity and Performance Management, 62(1), 66-84.

12. Kurt, A., \&Zehir, C. (2016). The relationship between cost leadership strategy, total quality management applications and financial performance.

13. Lau, A. W., Li, Y. S., Tang, S. L., \& Chau, K. W. (2016). TQM application by engineering consultants in Hong Kong. The TQM Journal, 28(4).

14. Mwaniki, C., \&Okibo, B. W. (2014). Effects of total quality management on financial performance in the banking sector: a case study of national bank of Kenya. IOSR Journal of Economics and Finance (IOSR-JEF), e-ISSN, 2321-5933.

15. O'Neill, P., Sohal, A., \& Teng, C. W. (2016). Quality management approaches and their impact on firms' financial performanceAn Australian study. International Journal of Production Economics, 171, 381-393. 
16. Rigby, D., \& Bilodeau, B. (2015). Management Tools \& Trends 2015. London, Bain \& Company.

17. Rigby, D., \& Bilodeau, B. (2015). Management Tools \& Trends 2015. London, Bain \& Company.

18. Sharma, M., \&Kodali, R. (2008). TQM implementation elements for manufacturing excellence. The TQM Journal, 20(6), 599621 .

19. Subrahmanya Bhat, K., \&Rajashekhar, J. (2009). An empirical study of barriers to TQM implementation in Indian industries. The TQM Journal, 21(3), 261-272.

20. Talib, F., Rahman, Z., \& Qureshi, M. N. (2011). Analysis of interaction among the barriers to total quality management implementation using interpretive structural modeling approach. Benchmarking: An International Journal, 18(4), 563-587.

21. Valmohammadi, C., \&Roshanzamir, S. (2015). The guidelines of improvement: Relations among organizational culture, TQM and performance. International Journal of Production Economics, 164, 167-178.

22. Witjaksono, A. D. (2012). The Difference of TQM Practice and Organization Performance between TQM Firms and Non TQM Firms. In 2nd International Conference on Management, Economics and Social Sciences (ICMESS'2012) June. 
